\title{
Problem-solving Abilities Through Integrated Learning Nested Models in Terms of the Initial Abilities of the Pre-service Elementary School Teacher
}

\author{
A D I Sari ${ }^{1 *}, \mathrm{~T} \mathrm{Herman}^{2}$

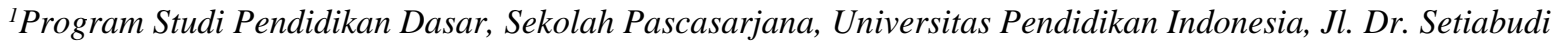 \\ No.299, Bandung 40154, Indonesia \\ ${ }^{2}$ Sekolah Pascasarjana,Universitas Pendidikan Indonesia, Jl. Dr.Setiabudi No. 229, Bandung 40154, Indonesia \\ *Corresponding author: tatherman123@gmail.com
}

\begin{abstract}
The low problem-solving ability of prospective pre-service elementary school teachers needs serious attention. Because students are prospective teachers who when they become teachers must equip their students with problem-solving skills. Therefore it is necessary to have a solution to overcome these problems. This study aims to obtain an overview of the problem-solving abilities of students who obtain integrated mathematics learning with the nested model in terms of the initial mathematical abilities of PGSD students. This research was conducted using a quasi-experiment. Problem-solving ability as the dependent variable, integrated learning, and early mathematical ability as independent variables. Data analysis used twoway Anova. Problem-solving ability data is taken through a problem-solving ability test, and students' initial mathematical abilities are seen from the midterm exam results. The results showed that (1) the application of Integrated Learning in mathematics learning made a positive contribution to students' problem solving abilities. This can be seen from the results of the research which show that there are differences in mathematical problem solving abilities between students who get Integrated Learning and those who get Fragmented Learning; (2) the level of students' initial mathematical abilities made a positive contribution to problem solving abilities. This can be seen from the results of the research which show that there are differences in students' initial mathematical abilities; (3) there is an interaction effect between Integrated Learning and early mathematical abilities on problem solving abilities.
\end{abstract}

Keywords: problem solving, learning models, elementary school, teacher

\section{INTRODUCTION}

Problem solving is an important component of instructional objectives in mathematics curricula in various countries, including Indonesia [1,2,3]. But in fact, not all students can achieve the instructional goals that have been set. The inadequacy of the objectives can be seen from the low ability of students to solve problems, especially in the form of word problems $[4,5,6,7]$. The low ability of students' problem solving shows the low mathematical ability of the students [8]. This is indicated by the results of the world assessment or PISA, students' mathematical abilities are ranked 72 out of 78 participating countries with a score of 379 out of 489 average international scores [9]. In addition, from the TIMSS assessment results, Indonesian students' mathematical abilities are ranked 44th out of 49 participating countries with a score of 397 out of 500 average international scores [10]. The low mathematical ability of students needs to be examined from various factors.

According to Emil Durkheim, "The success of education depends on the teacher, and the unsuccessful education depends on the teacher"[11].
The success or failure of education is very dependent on the teacher. The next factor is students, of course, other factors affect the success of education but the effects are not as big as the factors of teachers and students [12]. Agree with Heyneman \& Loxley [13] in their research, that the factor that determines the quality of education including student achievement is the teacher who affects one-third of the percent. This statement, of course, also applies to the success of mathematics education, especially to students' problem-solving abilities.

The teacher is a profession that requires special knowledge and skills to meet the needs of its students [14]. One of the student's needs is to acquire instruction until the student reaches the stage of optimal personal development. Professional teachers are teachers who can help their students learn [15]. However, in research conducted by Romanov et al [16]shows that the teacher is still having difficulty solving problems. Whereas teachers are the spearhead of education, so being a teacher is required to be able to master various abilities to equip students, including problem solving skills. Therefore, this basic ability has been instilled since 
the teacher was still in college, including in the primary school teacher education department (PGSD).

Primary School Teacher Education (PGSD) is an institution that is obliged to prepare elementary school teachers to be educated to become professional classroom teachers [17]. One of the indicators in professional competence that must be possessed by prospective elementary school teacher students is being able to implement conceptual, procedural knowledge, and their relationship in solving math problems and being able to apply them in everyday life (Ministry of National Education, 2007). Problem solving in mathematics is one of the abilities that must be mastered by prospective elementary school teacher students[14]. Prospective teacher students need to master the ability to solve mathematical problems, because this competence is needed in addition to equipping the students themselves as well as to equip their students later, to be ready to face the challenges of an increasingly developing world [18].

However, in reality, many elementary school teacher candidates still have difficulty solving problems. This is indicated by several research results that state that the mathematics problem solving ability of prospective teacher students, especially elementary school teachers, is still low. Students cannot solve non-routine problem problems according to the stages of the pattern. This is because students are less accustomed to solving non-routine problems and lack information about problem-solving strategies $[14,18,19]$. This condition must be immediately observed by educators and education observers, especially in the Elementary School Teacher Education Study Program. This is because these students will later become teachers who are responsible for instilling concepts, attitudes, and skills, including problem solving skills in their students [14]. Therefore, educators must carry out learning that focuses on improving students' mathematical problem solving abilities.

Given the urgency of the role of problem solving in the field of mathematics learning, especially in the PGSD program and observing student difficulties, it is necessary to make immediate efforts to overcome these problems. This is because students are prospective teachers who when they become teachers must equip their students with problemsolving skills [14]. Alternative solutions that can be offered by researchers are in the form of curriculum integration using a nested model. Researchers offer alternative solutions in the form of curriculum integration using a nested model, with the hope that the mathematical knowledge obtained by students is more meaningful because it is integrated with other concepts and skills.

"The nested model truly is an enriching model for integrating any number of skills and attitudes, dispositions, or habits of mind into the focus lesson"[21]. The purpose of this quote is that the nested model of integrated learning is a pattern that integrates the skills, attitudes, character, or thinking habits of students which are the focus of lessons in a subject. The advantage of this nested model is that teachers can combine several concepts on competency standards, abilities, skills, and attitudes in one lesson [21,22]. The relationship between concepts, abilities, skills, attitudes in integrated learning adds to the meaning of the concepts being learned so that students feel the learning process is more meaningful to solve real problems in life.

One of the factors that affect problem solving ability is the initial ability of students. Each student has different initial abilities. Initial ability is the student's ability to solve routine problems that have been previously learned [24].

Based on the description above, the researcher is interested in researching problem-solving abilities in mathematics courses through integrated learning nested models in terms of the initial abilities of elementary school teacher education students. This study aims to obtain an overview of the problemsolving abilities of students who get mathematics learning through integrated learning nested models in terms of the initial mathematical abilities of PGSD students.

The hypotheses in this study are as follows.

- There are differences in problem solving abilities between students who get integrated learning nested models and separate learning

- There are differences in problem-solving abilities between students with high, medium, and low levels of mathematical ability

- There is an interaction effect between integrated learning nested models and the level of mathematical abilities on problem solving abilities

\section{METHOD}

This study used a quasi-experimental research design by comparing two different types of learning, namely integrated learning nested models and separate learning. The design is a $3 \times 2$ factorial experiment with Integrated Learning independent variables and separate learning (Fragmented Learning) conducted by the teacher. The dependent 
variable is the student's mathematical problem solving ability. While the control variable is the students' initial mathematical ability, namely high, medium, and low. The first group got integrated learning with the nested model with 10 students. The second group received a separate learning model of 10 people. Research implementation was carried out through closely monitored zoom media.

\subsection{Participants and Research Sites}

Participants in this research are several parties who are involved in the research either directly or indirectly. The giving of a test for categorizing students' problem-solving thinking skills was carried out by researchers within one week, therefore 2 field workers (zoom) were needed to supervise the implementation of this test on the entire population. Likewise, the implementation of the pre-test, learning, and post-test in each experimental class requires 2 professionals, namely two through the zoom application. So that researcher is required to be able to equalize the perceptions of all volunteers to align with the desired research flow.

The place in this research is in each house because this research will be conducted online with the help of zoom media and the Moodle application to download the test questions.

\subsection{Population and Sample}

Experimental research requires a population and a sample as a data source. Population and sample determination was carried out before the study was carried out. The population can be defined as a large group that is the scope of the study, while the sample is a small group that represents a large group.

The population in this study was the scores of the students' problem solving abilities in the 3rd semester of PGSD Universitas Muhammadiyah Gresik.

The sample is part of the number and characteristics of the population. To select a sample from a population there are several sampling techniques or sampling techniques. Various sampling techniques according to Nesselroade \& Grimm[25] There are two sampling techniques, namely Probability Sampling and Non-Probability Sampling. The sample used in this study used a saturated sampling technique, where all populations were used as research samples, namely 10 students in the treatment class and 10 students in the control class.

\subsection{Research Instruments}

The data collected in this study were the data on students' problem solving abilities in the experimental group and the control group. Categorization of student problem-solving abilities is measured using a test instrument. Furthermore, data on student problem-solving abilities is measured through problem-solving ability instruments which are arranged based on indicators of problem-solving abilities.

\subsection{Data analysis}

The results of the mathematics problem-solving ability test in the form of a score will be used to analyze differences in problem solving abilities between students who obtain integrated learning nested models and separate learning; differences in problem-solving abilities between students with high, medium, and low levels of mathematical ability; and the influence of the interaction between integrated learning nested models with mathematical abilities on problem solving abilities. The data obtained were grouped according to the problem and based on the grouping, the data were processed using two-way ANOVA with the help of the SPSS version 22 application by paying attention to the parametric prerequisite test.

\section{RESULTS AND DISCUSSION}

After the implementation of integrated learning, the nested model and separate learning in mathematics, PGSD students in semester 3 by paying attention to the students' initial mathematical abilities obtained through UTS scores in mathematics. Obtained the results of the parametric prerequisite test, namely the normality and homogeneity tests are shown in table 1 and table 2 .

The results of the SPSS Version 22 test in Table 1 show that the data is normally distributed, this is indicated by the sig value on the Shapiro-Wilk which shows a score of $0.063>0.05$. Whereas in table 2 shows that the sig value is $0.187>0.05$, this means that the sample is homogeneous. The results shown in Tables 1 and 2 show that the sample meets the parametric test prerequisites so that the Two Way Anova test can be continued. 
TABLE 1. Tests of Normality.

\begin{tabular}{|l|c|c|c|c|c|c|}
\hline \multirow{2}{*}{} & \multicolumn{3}{|c|}{ Kolmogorov-Smirnova } & \multicolumn{3}{c|}{ Shapiro-Wilk } \\
\cline { 2 - 7 } & Statistics & df & Sig. & Statistics & df & Sig. \\
\hline $\begin{array}{l}\text { Standardized Residual for } \\
\text { Problem Solving }\end{array}$ &, 178 & 20 &, 096 &, 910 & 20 &, 063 \\
\hline a. Lilliefors Significance Correction & \multicolumn{7}{|l}{} \\
\hline
\end{tabular}

TABLE 2. Levene's Test of Equality of Error Variances a

\begin{tabular}{|c|c|c|c|}
\hline \multicolumn{4}{|c|}{ Dependent Variable: Problem solving } \\
\hline $\mathrm{F}$ & $\mathrm{df} 1$ & $\mathrm{df} 2$ & Sig. \\
\hline 1,754 & 5 & 14 &, 187 \\
\hline $\begin{array}{l}\text { Tests the null hypothesis that the error variance } \\
\text { of the dependent variable is equal across groups. }\end{array}$ \\
$\begin{array}{l}\text { a. Design: Intercept + Learning + KAM + } \\
\text { Learning * KAM }\end{array}$ \\
\hline
\end{tabular}

Through the problem-solving ability test given to students after participating in mathematics learning by implementing Integrated Learning and Fragmented Learning, the score data for students' mathematical problem solving abilities was obtained. From the test score data for students' mathematical problem solving abilities, then the difference test was carried out using two-way ANOVA with the SPSS Version 22 application, which resulted in the following:

\subsection{Hypothesis Testing 1}

The first research hypothesis is that there are differences in problem-solving abilities between students who get Integrated Learning and Fragmented Learning. The statistical hypothesis and research hypothesis being tested are $\mathrm{H} 0: \mu 1=\mu 2$, and $\mathrm{H} 1: \mu 1 \neq \mu 2$. To test the hypothesis, the ANOVA test was used using SPSS version 22. The results obtained with the ANOVA test can be seen in Table 3 below.

TABLE 3. ANOVA Test Problem Solving Ability Test for students who get Integrated Learning and students who get Fragmented Learning.

\begin{tabular}{|l|r|r|r|r|r|}
\hline \multicolumn{7}{|c|}{ Tests of Between-Subjects Effects } \\
\hline Dependent Variable: Problem solving & \multicolumn{1}{l|}{} \\
\hline Source & $\begin{array}{c}\text { Type III Sum of } \\
\text { Squares }\end{array}$ & df & Mean Square & F & Sig. \\
\hline Corrected Model & $2596,617 \mathrm{a}$ & 5 & 519,323 & 6,478 &, 003 \\
\hline Intercept & 79942,561 & 1 & 79942,561 & 997,204 &, 000 \\
\hline Learning & 985,227 & 1 & 985,227 & 12,290 &, 003 \\
\hline KAM & 620,617 & 2 & 310,308 & 3,871 &, 046 \\
\hline Learning * KAM & 865,950 & 2 & 432,975 & 5,401 &, 018 \\
\hline Error & 1122,333 & 14 & 80,167 & & \\
\hline Total & 83225,000 & 20 & & & \\
\hline Corrected Total & 3718,950 & 19 & & & \\
\hline a. R Squared =, 698 (Adjusted R Squared =, 590) & & & & \\
\hline
\end{tabular}

From the table of tests of between-subject effect which shows differences in learning in table 3, the value of $\mathrm{Sig}=0.03$ is obtained. The $\mathrm{H} 0$ test criterion is accepted if the significance value is greater than the value $\alpha$. Therefore the significance is smaller than the value $\alpha=0.05$ then $\mathrm{HO}$ is rejected. And H1 is accepted. This shows that there are differences in problem-solving abilities between students who get Integrated Learning and Fragmented Learning. This means that mathematics learning that applies
Integrated Learning can provide results in the form of student problem solving abilities that are better than separate mathematics learning (Fragmented Learning). This result is also in line with the research conducted by Habibah \& Maryanto[26] which shows that there is a significant difference between integrated learning with nested models and separate learning (Fragmented Learning). 


\subsection{Hypothesis Testing 2}

The second research hypothesis is that there are differences in problem-solving abilities between students with high, medium, and low initial mathematical abilities.

The statistical hypothesis and research hypothesis being tested are $\mathrm{H} 0: \mu 1=\mu 2=\mu 3$ and $\mathrm{H} 1$ : Not H0. To test the hypothesis, the ANOVA test was used using SPSS version 22. The results of the
ANOVA test for differences in problem solving abilities based on students' initial mathematical abilities can be seen in table 3 above, namely with a sig value of $0.046<0.05$ which indicates that there are differences in problem solving abilities of students with high, medium, and low initial mathematical abilities and to analyze which pair of groups were different, I used the SPSS Post Hoc test of LSD and the results were as follows:

TABLE 4. ANOVA Post Hoc Test Students' Problem Solving Ability Test in terms of their initial mathematical abilities.

\begin{tabular}{|c|c|c|c|c|c|c|}
\hline \multicolumn{7}{|c|}{ Multiple Comparisons } \\
\hline \multicolumn{7}{|c|}{$\begin{array}{l}\text { Dependent Variable: Problem solving } \\
\text { LSD }\end{array}$} \\
\hline \multirow[t]{2}{*}{ (I) KAM } & \multirow[t]{2}{*}{ (J) KAM } & \multirow{2}{*}{$\begin{array}{l}\text { Mean Difference } \\
\text { (IJ) }\end{array}$} & \multirow[t]{2}{*}{ Std. Error } & \multirow[t]{2}{*}{ Sig. } & \multicolumn{2}{|c|}{ 95\% Confidence Interval } \\
\hline & & & & & Lower Bound & Upper Bound \\
\hline \multirow{2}{*}{ Low } & Moderate & 1.17 & 5,169 &, 825 & -9.92 & 12.25 \\
\hline & High & $11.92 *$ & 4,835 &, 027 & 1.55 & 22.29 \\
\hline \multirow{2}{*}{ Moderate } & Low & -1.17 & 5,169 &, 825 & -12.25 & 9.92 \\
\hline & High & $10.75 *$ & 4,835 & 043 &, 38 & 21.12 \\
\hline \multirow{2}{*}{ High } & Low & $-11.92 *$ & 4,835 &, 027 & -22.29 & -1.55 \\
\hline & Moderate & $-10.75 *$ & 4,835 &, 043 & -21.12 &,- 38 \\
\hline \multicolumn{7}{|c|}{$\begin{array}{l}\text { Based on observed means. } \\
\text { The error term is Mean Square (Error) }=80,167 \text {. }\end{array}$} \\
\hline
\end{tabular}

From table 4.Multiple Comparisons with different problem-solving abilities based on the level of students' initial mathematical ability are high and low because the sig value is 0.027 and the high level is moderate because the sig value is 0.043 , these sig values are smaller than 0.05 with attention the average value then the problem-solving ability at a high level with low level is higher than high level with medium level.

\subsection{Hypothesis Testing 3}

The hypothesis tested is as follows:

$\mathrm{HO}=$ there is no interaction effect between Integrated Learning and early mathematical abilities on students' mathematical problem solving abilities $\mathrm{H} 1=$ there is an interaction effect between Integrated Learning and early mathematical abilities on students' mathematical problem solving abilities

The interaction that occurs between learning and early mathematical abilities on students' problem solving abilities can be seen in table 4 . From the results of the analysis, it is found that the significance value is 0.018 . Therefore the significance is smaller than the value $\alpha=0.05$, then $\mathrm{H} 0$ is rejected and $\mathrm{H} 1$ is accepted. This means that there is an interaction effect between Integrated Learning and early mathematical abilities on students' mathematical problem solving abilities.

\section{CONCLUSION}

Based on the results of the analysis and discussion that have been described in the previous section, this section will provide the following conclusions:

- The application of Integrated Learning in mathematics learning makes a positive contribution to students' problem solving abilities. This can be seen from the results of research which show that there are differences in mathematical problem-solving abilities between students who get Integrated Learning and those who get Fragmented Learning.

- The level of students' initial mathematical ability makes a positive contribution to problem solving abilities. This can be seen from the results of the research which show that there are differences in students' initial mathematical abilities.

- There is an interaction effect between Integrated Learning and early mathematical abilities on problem solving abilities 


\section{REFERENCES}

[1] T. Tambychik and T. S. M. Meerah, "Students' difficulties in mathematics problem-solving: What do they say?," Procedia - Soc. Behav. Sci., vol. 8, no. 5, pp. 142-151, 2010, doi: 10.1016/j.sbspro.2010.12.020.

[2] A. Panaoura, "Improving problem solving ability in mathematics by using a mathematical model: A computerized approach," Comput. Human Behav., vol. 28, no. 6, pp. 2291-2297, 2012, doi: 10.1016/j.chb.2012.06.036.

[3] S. Vicente, R. Sánchez, and L. Verschaffel, "Word problem solving approaches in mathematics textbooks: a comparison between Singapore and Spain," Eur. J. Psychol. Educ., vol. 35, no. 3, pp. 567-587, 2020, doi: 10.1007/s10212-019-00447-3.

[4] U. I. Kusuma and H. Retnawati, "Analysis of Sixth Graders' Difficulties in Solving Mathematics Word Problems on Whole Numbers, Fractions, and Decimals," J. Phys. Conf. Ser., vol. 1320, no. 1, 2019, doi: 10.1088/1742-6596/1320/1/012008.

[5] C. Scheibling-Sève, E. Pasquinelli, and E. Sander, "Assessing conceptual knowledge through solving arithmetic word problems," Educ. Stud. Math., vol. 103, no. 3, pp. 293311, 2020, doi: 10.1007/s10649-020-099383.

[6] I. Di Leo and K. R. Muis, "Confused, now what? A Cognitive-Emotional Strategy Training (CEST) intervention for elementary students during mathematics problem solving," Contemp. Educ. Psychol., vol. 62, no. May, p. 101879, 2020, doi: 10.1016/j.cedpsych.2020.101879.

[7] N. Pongsakdi, A. Kajamies, K. Veermans, K. Lertola, M. Vauras, and E. Lehtinen, "What makes mathematical word problem solving challenging? Exploring the roles of word problem characteristics, text comprehension, and arithmetic skills," ZDM - Math. Educ., vol. 52, no. 1, pp. 33-44, 2020, doi: 10.1007/s11858-019-01118-9.

[8] Herman Tatang, "Pembelajaran Berbasis Masalah untuk Meningkatkan Kemampuan Berpikir Matematis Tingkat Tinggi Siswa Sekolah Menengah Pertama," Educationist, vol. 1, no. 1, p. 3, 2007, [Online]. Available: http://ejournal.sps.upi.edu/index.php/educat ionist/article/view/28/22.

[9] OCDE, “OECD Multilingual Summaries
PISA 2018 Results (Volume I ) What Students Know and Can Do (Spanish)," vol. I, no. Volume I, pp. 2018-2020, 2019, [Online]. Available: http://oe.cd/disclaimer\%0Ahttps://www.oec d-ilibrary.org/docserver/a89c90e1-

es.pdf? expires $=1596231234 \&$ id=id\&accna me $=$ guest $\&$ checksum $=$ D1296FBB63BED1 CFB573C9D710E87BE9.

[10] TIMSS, “Timss 2015 International Results in Science Saved," Distrib. Sci. Achiev., 2015, [Online]. Available: http://timss2015.org/timss-

2015/science/student-

achievement/distribution-of-scienceachievement/.

[11] W. Dai, "Study on Total Compensation System of Independent College Teachers," vol. 205, no. Iccese, pp. 241-245, 2018, doi: 10.2991/iccese-18.2018.57.

[12] Wahyudin, "Kemampuan guru matematika, calon guru matematika, dan siswa dalam pembelajaran matematika: studi terhadap tingkat penguasaan guru matematika, calon guru matematika, dan siswa mata pelajaran matematika serta kemampuan mengajar para guru matematika," Aug. 1999, Accessed: Dec. 26, 2020. [Online]. Available: http://repository.upi.edu/.

[13] S. P. Heyneman and W. A. Loxley, "The effect of primary-school quality on academic achievement across twenty-nine high- and low-income countries.," Am. J. Sociol., vol. 88, no. 6, pp. 1162-1194, 1983, doi: $10.1086 / 227799$.

[14] E. Yayuk and H. Husamah, "The difficulties of prospective elementary school teachers in item problem solving for mathematics: Polya's steps," J. Educ. Gift. Young Sci., vol. 8, no. 1, pp. 361-378, 2020, doi: 10.17478/jegys.665833.

[15] R. M. Harden and J. Crosby, "AMEE guide no 20: The good teacher is more than a lecturer - The twelve roles of the teacher," Med. Teach., vol. 22, no. 4, pp. 334-347, 2000, doi: 10.1080/014215900409429.

[16] P. Y. Romanov, L. V. Smirnova, and O. A. Torshina, "Teaching ways of compiling tasks as the fundamentals of the development of professional competence of future mathematics teachers," Perspekt. Nauk. i Obraz., vol. 38, no. 2, pp. 442-452, 2019, doi: 10.32744/pse.2019.2.33.

[17] G. Roebyanto, "Matematika dasar untuk 
PGSD."

https://books.google.co.id/books?id=udssD

wAAQBAJ\&printsec $=$ frontcover $\& d q=$ Pem ecahan+Masalah+Matematika+untuk+PGS D\&hl=jv\&sa $=$ X\&ved $=2$ ahUKEwj2sq3Yq6 jtAhVJlEsFHWKyC1YQ6AEwAHoECAU QAg\#v=onepage\&q=Pemecahan Masalah Matematika untuk PGSD\&f=false (accessed Nov. 30, 2020).

[18] A. Wildgans-Lang, S. Scheuerer, A. Obersteiner, F. Fischer, and K. Reiss, "Analyzing prospective mathematics teachers' diagnostic processes in a simulated environment," ZDM - Math. Educ., vol. 52, no. 2, pp. 241-254, 2020, doi: 10.1007/s11858-020-01139-9.

[19] Y. Fitrianti, D. Suryadi, and Kusnandi, "PreService Mathematics Teachers Divisibility Construction," J. Phys. Conf. Ser., vol. 1315, no. 1, 2019, doi: 10.1088/17426596/1315/1/012045.

[20] A. H. Abdullah, N. H. Ibrahim, J. Surif, M. Ali, and M. H. Hamzah, "Non-routine mathematical problems among in-service and pre-service mathematics teachers," Proc. IEEE Int. Conf. Teaching, Assess. Learn. Eng. Learn. Futur. Now, TALE 2014, no. December, pp. 18-24, 2015, doi: 10.1109/TALE.2014.7062620.

[21] R. Fogarty, How to Integrate the Curriculla, vol. 53, no. 9. 2019.

[22] E. Köse, A. C. Johnson, E. Köse, and A. C. Johnson, "Women in Mathematics: A Nested Approach Women in Mathematics : A Nested Approach," Primus, vol. 1970, no. July, pp. 676-693, 2016, doi: 10.1080/10511970.2015.1132802.

[23] H. L. Sisitka and G. Raven, "Learning through cases : adopting a nested approach to case - study work in the Gold Fields participatory course initiative Learning through cases : adopting a nested approach to case-study work in the Gold Fields participatory course initiative," vol. 4622, no. May, 2016, doi: 10.1080/1350462032000173715.

[24] I. Sulistiawati, N. Arsyad, and I. Minggi, "Deskripsi Penalaran Siswa dalam Pemecahan Masalah Matematika pada Pokok Bahasan Barisan dan Deret Ditinjau dari Kemampan Awal," Issues Math. Educ., vol. 3, no. 2, pp. 111-118, 2019.

[25] K. P. Nesselroade and L. G. Grimm, Statistical Applications for the Behavioral and Social Sciences. 2018.

[26] N. K. Habibah and A. Maryanto, "The Influence of Nested Type of Integrated Science Learning Model on Students' Critical Thinking and Cooperation Skills," $J$. Sci. Educ. Res., vol. 4, no. 1, pp. 33-39, 2020, doi: 10.21831/jser.v4i1.34239. 